\title{
SOBRE A LENHA, LABAREDA SOU: POÉTICA DA MEMÓRIA EM UM CANTO RITUAL KRAHÔ ${ }^{1}$
}

\author{
Ian Packer ${ }^{1}$ \\ 1Universidade de Campinas, Campinas, São Paulo, Brasil
}

\begin{abstract}
Resumo: Apresento aqui a transcrição e a tradução da letra de um canto krahô, povo ameríndio falante de uma língua Jê e que vive no norte do estado do Tocantins. Este canto é um exemplar de um dos diversos gêneros de arte verbal encontrados entre os Krahô e que constituem formas expressivas centrais em seu vasto e complexo sistema ritual. Proponho aqui um exercício cruzado em que o comentário etnográfico enriquece a tradução e o comentário sobre a tradução enriquece a etnografia, ambos movimentos contribuindo para uma compreensão mais detalhada do texto e de seu contexto. A partir disso, interpreto esse canto como uma reflexão sobre seu próprio processo de transmissão e como local de elaboração de uma poética da memória.
\end{abstract}

Palavras-chave: Krahô; Artes Verbais; Tradução; Etnopoética; Memória

\section{ON A FIREWOOD, I AM BLAZE: POETICS OF MEMORY IN A KRAHÔ RITUAL CHANT}

Abstract: This paper presents the transcription and translation of the lyrics of a Krahô ritual chant, Amerindian people who live in the north of the

${ }^{1}$ Este artigo é parte da minha pesquisa de doutorado, em desenvolvimento, financiada pela FAPESP (processo N0 2015/00760-0) e pela CAPES, a quem agradeço pelo apoio. Esta pesquisa também fez parte do projeto "Sistemas regionais ameríndios em transformação", coordenado pelo Prof. Antonio Guerreiro (IFCH/ Unicamp) e financiado pela FAPESP (processo N0 2013/26676-0). Agradeço também a Ana Gabriela Morim de Lima, Antonio Guerreiro, Aurore Monod Becquelin, Bruna Franchetto, Majoi Gongora, Max Packer e Pierre Déléage pelos comentários feitos a uma versão preliminar deste artigo, e a Maxwell Miranda pela interlocução a respeito da língua krahô. 
state of Tocantins (Central Brazil) and and speak a Jê language. This chant is an exemplary piece of one of the several genres of verbal arts found among the Krahô, which constitute central expressives forms in their vast and complex ritual system. I propose here a cross-exercise in which the ethnographic commentary enriches the translation, and the commentary on translation enriches the ethnography, both movements contributing to a more detailed understanding of the text and its context. On that basis, I interpret this chant as a reflection on its own process of transmission and as a place of elaboration of a poetics of memory.

Key-words: Krahô; Verbal Arts; Translation; Ethnopoetics; Memory

\section{Introdução}

Apresento aqui uma tradução comentada de um canto krahô, povo ameríndio falante de uma língua Jê e que vive no norte do estado do Tocantins, no Brasil Central ${ }^{2}$. Trata-se de um exemplar de um dos diversos gêneros de arte verbal que podem ser encontrados entre os Krahô e que constituem uma forma de expressão central em seu vasto e complexo sistema ritual.

Idealmente, a execução deste canto deve ser realizada a duas vozes, por dois cantores que, cada qual associado a uma das meta-

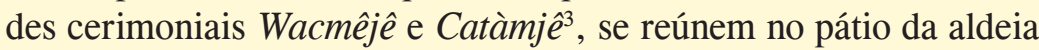
para uma performance em que se alternam em sua enunciação,

${ }^{2}$ Os Krahô se autodenominam mẽhĩ (em uma tradução aproximada, "corpo humano" ou "pessoa humana") e são falantes de uma língua pertencente ao conjunto dialetal Timbira oriental, filiado à família Jê Setentrional (tronco MacroJê). A denominação Timbira oriental se refere aos povos Canela-Apãnjêkra, Krĩkati, Gavião-Pykopjê, Gavião-Pàrcatêjê, Krẽjê e Canela-Ràmkôkamẽkra que, além de falarem variantes de uma mesma língua, compartilham uma série de características socioculturais: um mesmo sistema de parentesco, a morfologia circular e radial de suas aldeias, a prática das corridas de tora e um conjunto de narrativas míticas e de rituais em comum.

${ }^{3}$ A vida ritual krahô se organiza, em grande medida, em torno de uma série de pares de metades cerimoniais. A vinculação a algumas delas ocorre por meio do nome pessoal recebido, no caso de um menino, de um tio materno ou de um dos avôs e, no caso de uma menina, de uma tia paterna ou de uma das avós. 
sem jamais sobreporem suas vozes. No entanto, são poucos os cantores que o conhecem atualmente, fato lamentado pelos Krahô que, via de regra, indicam Francisco Pootyt, um senhor por volta dos 60 anos de idade e mestre ritual da aldeia Capitão do Campo, como um de seus últimos conhecedores e um dos últimos cantores capazes de executá-lo de maneira "bela" e "correta" (impej). Por raramente encontrar um outro cantor que possa atuar como seu interlocutor, Pootyt costuma executar este canto solitariamente, durante as cantorias de maracá, ou por ocasião da realização de algum dos grandes rituais krahô (amjîkin), atraindo imediatamente a atenção da audiência com a inconfundível beleza de sua voz e de suas palavras. Desse modo, ainda que o conhecimento deste gênero de arte verbal seja aberto e acessível a todos, ele vem se tornando cada mais associado à pessoa e à memória de Pootyt, a ponto de hoje em dia ele já ser socialmente referido simplesmente como Pootyt crer, "Canto de Pootyt". Ao longo de minha pesquisa de campo, tive a oportunidade de gravar uma curta performance realizada por dois cantores, mas como o público presente a julgou "ruim" e "feia" (ihkên), não reconhecendo seus executores como de fato bons conhecedores do gênero, é a transcrição e a tradução da versão solo do Canto de Pootyt que apresento aqui ${ }^{4}$.

Se este gênero verbal pode ser identificado como um "canto", esta não é, contudo, necessariamente a melhor forma de caracterizar a performance vocal por meio da qual ele é enunciado. Os próprios Krahô, aliás, costumam designá-lo também por meio de uma outra categoria meta-linguística: Mẽ icakôc xà, algo como "Nossas palavras" ou, como às vezes a traduzem os Krahô, "Nossa conversa", tradução que faz alusão à configuração dialógica de sua performance. Com efeito, se por um lado, o início e o final da performance (linhas 1-12 e 51-56, abaixo) se caracterizam por uma enunciação em estilo "arioso", com alongamento melódico da vogal da última palavra de cada linha, a enunciação

${ }^{4} \mathrm{O}$ registro sonoro original foi feito pelo Centro de Trabalho Indigenista (CTI) quando produziu o CD Amjëkĩn: música dos povos Timbira, em 2004. 
de sua parte central (linhas 20-46) se caracteriza por uma forma melódica especial, cuja pulsação rítmica acelerada e o estilo "recitativo" a distingue tanto da enunciação propriamente musical dos cantos (increr), quanto do padrão prosódico que caracteriza a fala (jarẽn) em registro cotidiano.

A caracterização deste gênero verbal por meio do contraste à fala e ao canto também pode ser aproveitada para caracterizá-lo do ponto de vista do conteúdo do que é contado/cantado. Se estabelecermos, como propuseram Seeger (2015) e diversos outros autores que se dedicaram ao estudo das artes verbais ameríndias ${ }^{5}$, um gradiente que nos permita contrastar as várias formas discursivas krahô (narrativas pessoais, mitos, chamados e conselhos públicos, diálogos cerimoniais, cantos, etc) em relação à fixidez de seu conteúdo verbal, a fala cotidiana, livre e espontânea, ocuparia o polo mínimo de estabilização, ao passo que os cantos ocupariam seu polo máximo. Isso porque, de modo geral, os Krahô concebem seus cantos como um conhecimento que deve ser transmitido verbatim de um cantor a outro e de uma geração a outra. Tal concepção se enraíza no fato que, conforme relatam diversas narrativas míticas, todos os cantos foram aprendidos por seus antepassados junto a uma miríade de alteridades não-humanas em um tempo/espaço (mam pjêe, "antiga terra", "primeira terra") em que homens, animais, plantas e todas as singularidades que compõem o mundo podiam falar e se comunicar entre si. Esta origem extra-humana e extra-temporal dos cantos se constitui como fonte de autoridade que confere grande estabilidade ao seu conteúdo, a qual ainda é reforçada pela concisão de suas letras e pelas repetições que caracterizam seu modo de enunciação. Não há, assim, lugar para a invenção propriamente dita de novos cantos e, caso um cantor altere o conteúdo de um canto ou nele insira palavras ou linhas de um canto distinto, tal modificação será percebida como um erro e o cantor inevitavelmente ouvirá comentários negativos por parte de sua audiência.

${ }^{5}$ Dentre eles, Sherzer (1983, 1990), Sherzer \& Urban (1986), Franchetto (1986), Cesarino (2011). 
À luz destas considerações, pode-se dizer que a forma discursiva da qual trato aqui ocupa uma posição intermediária. Por um lado, seu conteúdo é mais extenso e "narrativo" do que o conteúdo dos cantos e seu enunciador possui uma considerável margem de autonomia para determiná-lo, elaborando certos enunciados, imagens e metáforas de acordo com seu gosto e criatividade. Por outro, há certos topos e recursos retóricos que são constitutivos da forma poética do gênero e devem ser necessariamente utilizados por todo e qualquer cantor que decida entoá-lo. Assim, mais do que o conhecimento de um conteúdo inteiramente fixo e estável, a performance deste gênero verbal exige apenas o conhecimento prévio de um certo arcabouço de temas, sobre os quais o cantor é livre para improvisar e compor suas próprias variações. Como se verá abaixo, esta estrutura temática é constituída fundamentalmente: I) por uma referência elogiosa ao tempo e aos conhecimentos dos antepassados (linhas 31-34); II) por uma (meta)-referência à própria performance que o cantor realiza no pátio (linhas 25 e 35); III) pela (auto)-caracterização do cantor como se encontrando em uma situação penosa e difícil (linhas 28, 37 e 41). Articulados entre si, estes três temas permitem ao enunciador indexar seu próprio contexto e condições de enunciação no interior do canto, fazendo de sua perseverança em seguir cantando no pátio, apesar das condições adversas que enfrenta, uma espécie de elo entre o passado e o presente por meio do qual os conhecimentos dos antepassados continuam a ser transmitidos e ensinados às novas gerações.

\section{Da performance ao texto}

Passemos agora ao texto do Canto de Pootyt que, extraído e deslocado do evento ritual e da performance vocal dos quais faz parte, surge aqui transposto para o espaço da página de papel e assumindo a forma de um "poema". A fim de recriar algo do ritmo enunciativo e da carga dramática de sua enunciação original, apresento-o dividido em linhas e estrofes, divisão que também possibilita tornar 
saliente sua estrutura paralelística e algumas outras características que orientam sua elaboração verbal e sua organização formal.

A divisão do canto em linhas segue dois critérios (coincidentes) que caracterizam a performance vocal de Pootyt: as breves pausas feitas pelo cantor ao final de cada unidade entonacional e o uso recorrente do deítico kãm (que designa o lugar em que o cantor se encontra, o pátio), sempre pronunciado com destacada altura tonal de modo a marcar o início de uma nova unidade entonacional. Conforme já apontei acima, estas unidades são encadeadas em um ritmo bastante acelerado que, no entanto, é suspenso em determinados momentos por uma entonação mais doce e melodiosa, que sugere a transição a uma nova estrofe e o início de um novo "respiro-pensamento" (Franchetto "Traduzindo" 39). Esta transição também pode ser feita por meio da enunciação repetida de uma mesma linha com alturas tonais diferentes (como nas linhas 19-20, 30-31 e 37-38), repetição que gera um efeito recursivo que também caracteriza a forma retórica de outros gêneros verbais krahô.

A transcrição do canto em língua krahô foi realizada juntamente com Elton Hiku, morador e professor da aldeia Pé de Côco ${ }^{6}$. Vale dizer que a transcrição não segue a forma das palavras tal como realizadas no registro cotidiano da língua krahô, e sim acompanha as transformações fonológicas que elas sofrem ao se adequarem rítmicamente à forma prosódica especial do canto ${ }^{7}$. O trabalho de tradução em português, por sua vez, foi realizado em diversas etapas. Uma tradução inicial foi realizada juntamente com Hiku e com os cantores João Duruteu Xàj, Tito Hapykrit, Olegário Tejapoc e com o próprio Francisco Pootyt, colaboração sem a qual teria sido impossível compreender certas metáforas e o alcance do significado de determinados temas e passagens, cuja elucidação depende da compreensão de aspectos mais amplos do pensamento e da

6 Atualmente, Elton Hiku também é estudante da Licenciatura Intercultural Indígena na Universidade Federal de Goiás (UFG).

${ }^{7}$ Assim, por exemplo jõmprỳ ("caça") se torna jõmõprỳ (linhas 3 e 9), ajkàm ("juntos") se torna ajkàmà (linhas 17 e 18), kàr ("grito") se torna kàràrà (linha 23), krỳtre ("angico") se torna rỳtyre (linha 51), etc.

Cad. Trad., Florianópolis, v. 39, n $^{0}$ esp., p. 227-247, set-dez, 2019 
cosmologia krahô. A esta primeira etapa, seguiram-se sucessivas outras, em que me confrontei sozinho com o texto e elaborei a versão apresentada aqui. Se ainda bastante próxima do original em língua krahô, esta versão comporta também uma dose considerável de recriação poética, de minha autoria e inteira responsabilidade ${ }^{8}$. $\mathrm{O}$ significado de certas palavras e alguns dos desafios envolvidos em sua tradução serão comentados em detalhe mais adiante. Por ora, indico apenas que em dois momentos (linhas 28 e 34) introduzi entre colchetes informações ausentes no original, mas que são importantes seja para esclarecer o sentido de certas passagens, seja para acomodar melhor sua expressão em português.

Mẽ icakôc xà

Canto de Pootyt

1.

5.

10.

Wacõrêêê
Jajê cô
Jajê cô

Jajê cô

Jajê cô

Rê pa jõmõprì

Hêêe

Hêêe
Ninho orvalhado

Ninho orvalhado

De nossa caça

O quati

Ninho orvalhado

Ninho orvalhado

Ninho orvalhado

Ninho orvalhado

De nossa caça

O quati

Ninho orvalhado

Ninho orvalhado

Hêêê

Hêêê

${ }^{8}$ Publiquei também uma versão em inglês deste canto, onde adotei critérios de apresentação e de tradução ligeiramente diferentes dos adotados aqui. Cf. Packer "Krahô - Pootyt's chant". 
15.

Cute ta jỹre

Cute ta jỹre

Ajkãmã jupjêrê

Ajkãmã irũnũ

Nãmã aric quiri

20.

Nãmã aric quiri

Kãmã amã amjĩ jikwa xà cacro pej ti te

Kãmã amã jũmãn nõ pê ri mã

Kãmã kàràrà ti jê nõ mã

Kãmã amã tahnã amjĩ to

ankrê nẽ

25. Wa kãmã ita reri mã

Kãmã mẽ cupãmũjê nõ japuhnã

Kãmã kàràrà ti jê nõ to

Kãmã hũjakry mã rỳquê ti

Kãmã amjĩ caprĩ to xãmre

$$
\text { rê nẽ }
$$

30. Mẽr ampo nãnãnre nã

Mẽr ampo nãnãnre nã

Pê ajco quêtê mam mẽ cupãmũjê nõ te harikwa

Jôtô ti kàràrà ti jê nõ

Jôtô ti to kãmã cuhê to ipa reri $m \tilde{a}$

35. Wa kãmã ita reri mã

Wa kãmã ita reri mã

Kãmã ipê cacôxàre te

Kãmã ipê cacôxàre te

Kãmã ajpẽn japuhnã rỳquê te hũjakry mã
Assim mesmo

Assim mesmo

Os que juntos nasceram

Os que juntos cresceram

Fiquem tranquilos

Fiquem tranquilos

Deitados próximos ao fogo

E sem fazer barulho

Com alguns belos cantos

Em silêncio fiquem

Eu estou aqui

Seguindo nossos antepassados

Com alguns de seus belos cantos [E ainda que] o Frio-Noite me enfraqueça

De pé permaneço

Mas então por que

Mas então por que

As palavras de nossos antepassados

E alguns dos belos cantos

Que de pé sempre cantavam

[já não se ouve mais?]

Eu estou aqui

Eu estou aqui

Eu - o sêmem dolorido

Eu - o filho

Venho sentir o Frio-Noite 
40. Kãmã mẽ cupãmũjê nõ japuhnã rỳquê te

Kãmã amjĩ nã hũjakry cupãj to xãm reri mã

Wa kãmã ita reri mã

Kãmã mẽ cupãmũjê nõ japuhnã nõ

Rỳquê te kàràrà ti jê nõ to

45. Kãmã amjĩ ijõ prõkwỳj nẽ Kãmã rỳquê te amjĩ kôt camẽn to mõr rê nẽ

\section{Hêêe}

Hêêe

Hêêe

50.

55.

$\begin{array}{cc} & \text { Rỳtyre nã } \\ & \text { Rỳtyre nã } \\ & \text { Wa icarêrê } \\ & \text { Rỳtyre } n \tilde{a} \\ & \text { Wa icarêrê }\end{array}$

Hêêe
E de pé, depois de nossos antepassados

Com o Frio-Noite sofrer

Eu estou aqui

Seguindo nossos antepassados

E alguns de seus belos cantos

Como uma mulher

Trago para perto de mim
Hêêê

Hêêê

Hêêê

Hêêê

Sobre a lenha

Sobre a lenha

Labareda sou

Sobre a lenha

Labareda sou

Hêêe

Deixo para mais adiante o comentário sobre as estrofes de abertura e de fechamento do canto, concentrando-me inicialmente em suas estrofes centrais, compreendidas entre as vocalizações "Hêêê, Hêêe". Esta parte do canto se inicia com o cantor pedindo a sua audiência - os que juntos nasceram e que juntos cresceram - que fiquem tranquilos e permaneçam em silêncio, enquanto ele começa a cantar no centro da aldeia. O cantor mobiliza, assim, a dualidade entre o círculo das casas - espaço essencialmente feminino e onde se desenrola a vida em família - e o pátio - espaço preponderante- 
mente masculino e onde se desenvolve a vida cerimonial -, dualidade central no pensamento e na sociocosmologia krahô e que está presente na organização de todo o canto, constituindo um aspecto fundamental de sua poética. É também por meio desta dualidade, por exemplo, que o cantor busca caracterizar seu contexto e suas condições de enunciação: enquanto todos os moradores da aldeia se encontram recolhidos no calor de suas casas, deitados próximos ao fogo (linha 21), ele, ao contrário, se encontra no pátio da aldeia, enfraquecido pelo "Frio-Noite" (hũjakry, linha 28).

A tradução de hũjakry por "Frio-Noite" é, aliás, uma das decisões de tradução que eu gostaria de comentar mais detalhadamente aqui, pois ela condensa uma série de informações importantes para a compreensão do canto. Conforme me explicaram inicialmente meus interlocutores krahô, hũjakry ${ }^{9}$ é uma palavra utilizada para designar o frio (kry) que ocorre em um momento e em um lugar específicos: trata-se, segundo eles, do frio que acomete as pessoas no pátio de noite (awcapàt kãm) e que alguns deles compararam à imagem do orvalho caindo sobre os corpos dos cantores e das cantoras - orvalho que, no entanto, é designado em língua krahô por uma outra palavra, awcapàt hy: literalmente, "grãos" ou "sementes da noite". A compreensão do sentido e do valor que a palavra hũjakry possui na poética do canto não pode se limitar, contudo, a estas explicações pontuais e imediatas, pois ela, e as noções de "frio" e de "noite" que por meio dela se associam, são amplamente elaboradas pelo pensamento krahô em distintas formas de conhecimento. A fim de compreendê-la devemos nos remeter, assim, aos domínios da mitologia, da cosmografia e a outros tipos

\footnotetext{
9 Segundo o linguista Maxwell Miranda (comunicação pessoal), o morfema -ü é um morfema (clítico) antipassivo que se desenvolveu historicamente a partir de um morfema com sentido genérico ou indefinido /- $\ddot{u}$ / que, na sintaxe da língua krahô, marca um objeto/complemento de alguns verbos transitivos e de nomes quando este é pressuposto ou cuja menção é irrelevante. Miranda identifica a presença de dois morfemas antipassivos distintos na língua krahô: aw, para verbos plenos, e $j / h-\tilde{u}$ para verbos nominalizados ou nomes plenos, como hũjakry, "frio de alguma coisa”.
}

Cad. Trad., Florianópolis, v. 39, nº esp., p. 227-247, set-dez, 2019 
de discurso ritual krahô, onde será possível encontrar um conjunto de elaborações que, se ausentes do conteúdo explícito da letra do Canto de Pootyt, estão virtualmente presentes na compreensão que os ouvintes nativos (ao menos aqueles mais versados nos conhecimentos e nas práticas rituais) têm desta palavra, cujos harmônicos cosmológicos podem ser ouvidos sobretudo quando ela é enunciada em contexto cerimonial.

Desse modo, um primeiro conjunto de elaborações a ser considerado pode ser encontrado na mitologia krahô e na maneira como a noite é ontologicamente concebida em uma série de narrativas míticas. Em uma delas, por exemplo, registrada por Melatti (88), um caçador vai sozinho à floresta para caçar pássaros jacu a fim de obter penas para emplumar suas flechas. Ele mata dois destes grandes pássaros, mas acaba se perdendo e não sabe mais como retornar à aldeia. Ele decide então fazer um jirau em cima dos galhos de uma árvore para passar a noite, quando começa a ouvir um barulho muito forte e se depara com os Awcapàtkrit, caçadores cujos olhos iluminam tão bem quanto lanternas e que por isso conseguem caçar com facilidade durante a noite. Inicialmente, o caçador solitário fica com medo destes seres, mas é protegido e alimentado pelo "chefe" (pahhi) dos Awcapàtkrit, retornando para sua aldeia alguns dias depois. Ao contar para seus parentes o que tinha acontecido, estes decidem ir ao encontro dos Awcapàtkrit e matar todos eles, por desconfiaram da presença daqueles seres estranhos na proximidade da aldeia. Da mesma forma, em uma outra narrativa, uma velha se afasta de seu grupo durante uma caçada coletiva de vários dias no mato e também se depara com um povo estrangeiro, que ela nunca tinha visto antes. Como conta o narrador da versão registrada por Melatti, de início "ela ficou pensando que era o povo dela, mas não; era a Noite. E eram muitos: homens, mulheres e moças" (Melatti 39). Assim, vê-se que no âmbito da especulação mítica sobre o mundo, a noite é concebida como uma coletividade que, à maneira de um coletivo humano, é composta por homens e mulheres que possuem um chefe, caçam e com quem é possível estabelecer tanto relações amistosas, quanto belicosas. 
Um outro conjunto de elaborações em torno do que é a noite, e agora também do que é o frio, pode ser encontrado na cosmografia. Segundo a concepção krahô, à leste (kỳj mã, literalmente, "alto") se situa o Pé-do-Céu, uma grande árvore que sustenta a cúpula celeste, enquanto à oeste (harã mã, lit. "baixo") se situa a aldeia dos mortos, por eles denominada Preeti. Sobre a região à leste onde se localiza o Pé-do-Céu, alguns Krahô explicaram a Vilma Chiara nos anos 80 que lá existe uma caverna de onde saem a noite e o frio, que são:

uma miríade de pequenos seres negros [...] que descem, correndo, em direção ao oeste. Eles são muito curiosos e, ao mesmo tempo, medrosos. Eles correm, eles se detêm; alguns são mais rápidos, outros demoram, de modo que quando o sol surge no céu à leste, ele os surpreende ainda percorrendo a Terra. Então eles se escondem nos buracos ou atrás dos objetos. É por isso que os buracos são negros e existe sombra (125).

Esta concepção em torno destes pequenos "seres-Frio" e "seres-Noite" e sua relação com a cosmografia krahô é interessante porque ela também é elaborada no âmbito de um outro gênero de arte verbal, o Kàjre jarkwa ("Canto da Machadinha"). Assim como o Canto de Pootyt, o Kàjre jarkwa também é classificado pelos Krahô como Mẽ icakôc xà ("Nossas palavras"), pois além das performances vocais de ambos serem semelhantes, o Kàjre jarkwa também é enunciado por meio da interação de dois cantores no pátio e sua estrutura temática é similar a do Canto de Pootyt. Similar, mas não idêntica, porque o Kàjre jarkwa elabora ainda um tema suplementar, ausente do Canto de Pootyt, o qual diz respeito ao mito de origem da Machadinha ${ }^{10}$.

${ }^{10}$ Neste sentido então, o Canto de Pootyt e o Canto da Machadinha devem ser concebidos como sub-gêneros de um gênero mais amplo, que os engloba. E com 
A Machadinha é um artefato de pedra polida de grande prestígio ritual que, conforme conta uma narrativa mítica, foi obtida pelos antepassados krahô no Pé-do-Céu. Por razões de espaço, não posso me alongar aqui na descrição desta narrativa e das particularidades do regime enunciativo por meio da qual ela é narrada na performance do Kàjre jarkwa ${ }^{11}$. De todo modo, é preciso ressaltar que ao incorporar referências à mitologia e à cosmografia, o Kàjre jarkwa fornece uma série de informações suplementares sobre hũjakry, dando a ele grande desenvolvimento narrativo, conceitual e poético. Assim, por exemplo, diz-se que hũjakry parte correndo do Pé-do-Céu em direção ao oeste, onde se abriga em um grande e raso rio. Ao longo deste percurso, sucessivas vezes descrito ao longo do Kàjre jarkwa, ele se esconde em diversos lugares onde gosta de se abrigar (na mata escura, no oco das árvores, na toca dos bichos, sob as folhas e sob as penas de um jacu...) até chegar à aldeia, onde encontra o cantor. Neste momento de seu trajeto, hũjakry é então explicitamente apresentado como uma entidade que "deseja se tornar gente" (amjĩ to jĩ prãm) e, em outra passagem, como uma entidade que possui mãos, com as quais atinge o cantor ao passar pelo pátio, enchendo-lhe de medo e, como Pootyt também diz em seu canto, fazendo-o sofrer e tornando-o fraco (linhas 28 e 41).

Esta capacidade de transformação de hũjakry e seu gosto por lugares ermos, turvos e sombrios evocam ainda um outro conjunto de elaborações cosmológicas, desta vez relativas à condição ontológica dos carõ, ou melhor, dos mẽcarõ, palavra que designa

efeito, ao compará-los, os Krahô se referem a performances como a de Pootyt como Mẽ icakôc kryjre, "Nossas pequenas palavras", ao passo que se referem ao Canto da Machadinha como Mẽ icakôc cati, "Nossas grandes palavras".

${ }^{11}$ Em linhas gerais, o que ocorre no Kàjre jarkwa é que a Machadinha deixa de ser apenas um tema narrativo para se tornar também sujeito da enunciação. Cuidadosamente enfeitada, ela é empunhada pelos cantores durante a performance, deslocando-se do passado mítico e se manifestando "em pessoa" no pátio da aldeia, onde interage com os cantores e se torna narradora de sua própria história. Em minha tese de doutorado, em preparação, desenvolvo esta análise e apresento a transcrição e a tradução do texto de uma performance do Kàjre jarkwa. 
os "espíritos" ou "duplos" de pessoas recentemente falecidas que ainda vagam pela floresta e pelo entorno da aldeia ${ }^{12}$. Com efeito, um dos principais atributos dos mẽcarõ é sua transformabilidade constante, decorrente do fato de já não possuírem um corpo que lhes dê uma forma estável e contornos precisos. Como contou um senhor Krahô a Morim de Lima:

\begin{abstract}
O wajaka [xamã] conta que mẽcarõ fica andando, né? Quando é de dia, ele fica em algum lugar frio ou algum tronco grande, árvore grande, ele fica encostado naquela árvore. Pode se transformar em algum pássaro ou sapo também. Transforma e fica lá na sombra quietinho. Então o mẽcarõ fica ali... (287).
\end{abstract}

Se de dia os mẽcarõ se escondem, transformados em outros seres, de noite eles se aproximam da aldeia para reencontrar seus parentes vivos, aparecendo-lhes em seus sonhos ou quando estes se encontram sozinhos em algum lugar - como o cantor no pátio. A evocação subliminar da ontologia dos mẽcarõ na descrição do comportamento de hũjakry é reforçada ainda pela indicação, no Kàjre jarkwa, de que este segue para o oeste após passar pelo corpo do cantor, direção em que se situa, como disse, a aldeia dos mortos.

Vê-se, então, que por trás da palavra hũjakry se descortina uma vasta constelação de concepções que elaboram o frio e a noite como uma multiplicidade de agentes dotados de uma densidade corporal própria e que possuem capacidades análogas às humanas. De modo algum se trata, portanto, de um simples fenômeno climático, o frio da noite (a noite como momento em que ocorre o frio) ou uma noite fria (o frio como atributo da noite) - traduções que procurei evitar por meio da justaposição Frio-Noite e do uso de iniciais

${ }^{12}$ Carõ é também a palavra usada em língua krahô para designar a sombra e qualquer outro tipo de imagem (como reflexos no espelho e na água, fotografias etc).

Cad. Trad., Florianópolis, v. 39, n $^{0}$ esp., p. 227-247, set-dez, 2019 
maiúsculas. Mais do que mera ausência de luz e de calor, a presença do Frio-Noite no pátio da aldeia deve ser compreendida como a presença de uma entidade personificada que, concebida ora de maneira singular, ora múltipla, se dirige deliberada e intencionalmente ao encontro do cantor, que dela busca proteger não apenas a si mesmo mas, como me esclareceu Pootyt durante a exegese do canto, toda a aldeia.

Assim, o confronto do cantor com o Frio-Noite confere a sua performance uma atmosfera agonística, a qual é ainda reforçada pela imagem escolhida por Pootyt para se referir a si mesmo e à situação que ele enfrenta no pátio: eu - o sêmen dolorido (linha 37), imagem que faz alusão simultaneamente à paternidade (sêmen) e à dor sentida pela mãe no parto e que constitui uma metáfora para "filho" (significado literal que, por sua vez, aproveito na linha 38). Esta auto-caracterização do cantor como um filho ecoa, aliás, na expressão mẽ cupãmũjê nõ (linhas 26, 32, 40 e 43), em cuja composição encontramos um termo de parentesco correlato: "pai" (pãm). No entanto, se estas imagens recorrem ao idioma da filiação, de forma alguma elas devem ser compreendidas como constituindo uma referência de um filho a seu genitor e sim como expressão de uma relação mais ampla e complexa. Indicativo disso é o fato de que a palavra "pai" (pãm) se faz acompanhar nesta expressão por morfemas que indicam sua pluralidade (mẽ), seu distanciamento e/ou falecimento (jê) e sua indefinição $(n \tilde{o})^{13}$, estratégia semântica que tem por efeito despersonalizar e generalizar

${ }^{13} \mathrm{O}$ morfema jê, além de também ser um sufixo pluralizador, indica falecimento quando aposto a certos termos de parentesco, como por exemplo em ikrajê, "meu falecido filho", e em iprõjê, "minha falecida esposa". Ele pode ser utilizado ainda como um vocativo para se referir a afins (sogro, cunhado, genro, etc.). $\mathrm{O}$ morfema nõ, por sua vez, é um pronome indefinido que, conforme o contexto, comporta traduções como "algum", "alguns", "outro", "outros". Além disso, ele também é utilizado na terminologia de parentesco krahô para expressar o parentesco classificatório, como por exemplo em inxũ nõ, "meu outro pai" (um irmão do pai) ou mẽ ikra nõ, "meus outros filhos". Em outro trabalho, discuto uma outra variação desta forma e seu emprego no âmbito de um outro gênero verbal krahô. Cf. Packer "Mẽ aquêtjê jakàmpê. 
este termo de parentesco e por meio dele designar um conjunto mais amplo de pessoas: em uma tradução literal, "alguns de nossos falecidos pais", ou, como costumam traduzir os Krahô de modo mais sintético, os "antigos"- ou ainda, como prefiro aqui, "os antepassados".

Vale esclarecer que esta referência de Pootyt aos antepassados não deve ser compreendida como expressão da existência de algo como um "culto aos ancestrais", à maneira do que se verifica entre os povos africanos, que em suas práticas rituais e em suas artes verbais preservam uma prodigiosa memória em torno de mortos específicos e nomeados, aos quais os vivos permanecem genealogicamente ligados por meio de suas linhagens familiares. Ao contrário, entre os povos ameríndios predomina a concepção, formulada com ênfase justamente pela etnografia krahô de Carneiro da Cunha, de que os "mortos são outros" e se tornam inimigos dos vivos, de modo que eles devem ser afastados - assim como o Frio-Noite, que assola o cantor no pátio. No entanto, como diversos etnólogos americanistas vêm notando, dentre os quais Chaumeil, Graham, Déléage, Guerreiro e Heurich, citados na bibliografia, o inegável esforço cosmopolítico realizado pelos povos ameríndios para romper relações com os mortos e esquecê-los não deve obscurecer o fato de que eles também realizam um considerável esforço em sentido contrário, buscando produzir algum tipo de continuidade com os mortos que seja socialmente produtiva - continuidade, justamente, de seus aspectos memoráveis e que devem permanecer presentes na vida dos vivos.

Desse modo, ao evocar a figura dos antepassados e se apresentar como um "filho" em situação penosa, Pootyt ancora sua performance em uma dimensão existencial e sociocosmológica mais ampla, no interior da qual o fato de estar cantando de pé e aqui (no pátio) deixa de ser mera alusão a uma postura e a um espaço atuais para se tornar expressão de uma complexa posição enunciativa: o cantor canta como cantavam os antepassados e, ao fazê-lo, ocupa seu lugar, tornando-se (ainda que apenas momentaneamente, somente durante o tempo de sua performance) um deles: um antepassado vivo. Quanto a isso, vale esclarecer ainda que o termo que produz esta ideia de 
continuidade entre os antepassados e o cantor (japuhnã), mais do que indicar uma pessoa que vem depois de alguém (um sucessor), indica alguém que vai depois (um seguidor), como a última pessoa de uma fila, que segue os passos daqueles que caminham a sua frente, acompanhando-os. Neste sentido, os antepassados, mais do que mortos afastados e deixados para trás, constituem um modelo de pessoa e um modo de vida a ser (per)seguido e constantemente (re)produzido por meio da (re)transmissão de seus conhecimentos e de seus "fortes gritos" - tradução literal de kàr ti, que recrio como "belos cantos" nas linhas 23, 27, 33 e 44.

Nas linhas finais destas estrofes centrais, os cantos dos antepassados são comparados ainda a uma mulher; ou melhor, a ação (temporal) do cantor de se lembrar e transmitir os cantos dos antepassados é comparada à ação (espacial) da vinda de uma mulher para perto dele (linhas 45-46). Esta imagem remete à performance de um outro gênero de cantos, os cantos de maracá (cohtoj jarkwa), cotidianamente cantados no pátio da aldeia por meio da presença conjunta não de dois cantores (como no caso dos Mẽ icakôc xà), mas de um cantor e das mulheres da aldeia, que compõem uma espécie de coro que canta com ele. Geralmente, a performance destes cantos se inicia com o cantor sozinho no pátio, onde ele canta alguns cantos iniciais para acordar a aldeia e, em seguida, passa a chamar as mulheres para virem cantar com ele. Esta interação entre homens e mulheres é marcada por um certo ar de disputa entre eles, e as mulheres costumam dizer que sua presença e sua voz são como lenha para o cantor, esquentando-o para que ele toque bem seu maracá e cante muitos cantos diferentes para elas - metáfora aproveitada por Pootyt na conclusão de seu canto (linhas 51, 52 e 54). Assim, se no início de sua performance Pootyt se encontrava de pé, sozinho e enfraquecido pelo Frio-Noite que se abate sobre ele no pátio, enquanto seus ouvintes se encontravam deitados e aquecidos em suas casas, agora, próximo ao final do canto, ele se encontra na companhia dos cantos dos antepassados que, me esclarecem meus interlocutores, o aquecem como uma mulher. Esta transformação da condição do cantor é elaborada de maneira con- 
densada nas estrofes iniciais e finais do canto que, depois de termos percorrido este trajeto até aqui, podemos enfim comentar.

Como expliquei anteriormente, estas partes são enunciadas de modo mais melódico e seu conteúdo pode variar de um cantor a outro, sendo eles livres para escolher as imagens com as quais querem começar e concluir o canto. Na curta performance a duas vozes que pude gravar, por exemplo, um dos cantores descreveu uma coruja (tôtôtre) de penas arrepiadas e eriçadas no início de seu canto, enquanto o outro preferiu se dirigir a seu interlocutor, referindo-se a ele como "meu grande amigo" (ikwỳnõ ti). Pootyt, por sua vez, optou por descrever um quati em seu "ninho orvalhado". Em uma tradução literal, este ninho estaria simplesmente "molhado" ou "úmido" (cô é água), mas procurei aproveitar a imagem do orvalho utilizada por meus interlocutores ao me falarem sobre as qualidades do Frio-Noite, e isso não só por achá-la bonita, mas também para já insinuar ali aquilo que o leitor terá talvez compreendido: é o cantor esse quati que passa frio no pátio, é um quati esse cantor que passa frio em seu ninho. Além de ser uma metáfora para a condição do cantor, esta imagem é também, conforme me foi explicado, o agenciamento por Pootyt de algumas características e afecções-Quati - sua ferocidade e valentia, por exemplo - que lhe ajudarão a seguir no pátio e a enfrentar o Frio-Noite.

A esta imagem inicial, Pootyt responde e complementa com a imagem que, com grande esmero poético e destreza verbal, ele compôs para encerrar seu canto. Aquecido pela memória e pela enunciação dos belos cantos dos antepassados (sua lenha ${ }^{14}$ ), o bravo cantor-Labareda crepita noite adentro no pátio da aldeia:

14 Rỳtyre (krỳtre) é, literalmente, o nome da árvore angico (Anadenthera macrocarpa), cuja lenha é apreciada pelos Krahô em razão de sua boa e longa capacidade de combustão. 


\title{
Sobre a lenha
}

\author{
Sobre a lenha
}

\section{Labareda sou}

Sobre a lenha

Labareda sou

\section{Referências}

Chaumeil, Jean-Pierre. "Bonnes, flutes and the dead: memory and funerary treatments in Amazonia". In: Fausto, Carlos; Heckenberger, Michael. Time and memory in indigenous Amazonia: anthropological perspectives. Gainesville: University Press of Florida, 2007, p. 243-283.

Carneiro da Cunha, Manuela. Os mortos e os outros: uma análise do sistema funerário e da noção de pessoa entre os índios Krahô. São Paulo: Editora Hucitec, 1978.

Cesarino, Pedro de Niemeyer. Oniska: poética do xamanismo na Amazônia. São Paulo: Perspectiva/Fapesp, 2011.

Chiara, Vilma. L'homme et l'espace chez les indiens Krahô. État de Goiás (Brésil). Tese de doutorado. Paris: École des hautes Études em Sciences Sociales, 1982.

Déléage, Pierre. Le chant de l'anaconda: l'apprentissage du chamanisme chez les Sharanahua (Amazonie occidentale). Nanterre: Société d'Ethnologie, 2009. 
Franchetto, Bruna. Falar Kuikuro: estudo etnolinguístico de um grupo karibe do Alto-Xingu. Tese de doutorado. Rio de Janeiro: Museu Nacional/UFRJ, 1986.

Franchetto, Bruna. "Traduzindo tolo: "eu canto o que ela cantou que ele disse que...' ou 'quando cantamos somos todas hipermulheres'”. Estudos de Literatura brasileira contemporânea, [s.1], 53 (2018): 23-43. Scielo. 15/08/2019. http:// www. scielo.br/scielo.php?pid $=$ S231640182018000100023\&script $=$ sci abstract\&tlng $=$ pt.

Graham, Laura. Performing dreams: The discourse of Immortality among the Xavante of Central Brasil. Austin: University of texas Press, 2003.

Guerreiro Júnior, Antonio Roberto. Ancestrais e suas sombras: uma etnografia da chefia Kalapalo e seu ritual mortuário. Campinas: Editora da Unicamp, 2016.

Heurich, Guilherme Orlandini. Música, morte e esquecimento na arte verbal Araweté. Tese de doutorado. Rio de Janeiro: Museu Nacional/UFRJ, 2015.

Melatti, Julio Cesar. "Outras versões de mitos krahô". Página do Melatti. Web. 15/08/2019. http://www.juliomelatti.pro.br/craodados/craomitos.pdf.

Morim de Lima, Ana Gabriela. Brotou batata pra mim: cultivo, gênero e ritual entre os Krahô (TO). Tese de doutorado. Rio de Janeiro: UFRJ, 2015.

Packer, Ian. "Mẽ aquêtjê jakàmpê - No lugar de teus antepassados: um chamado ao pátio krahô”. Revista Linguística. 15.1 (2019a): 231-270. 15/08/2019. https:// revistas.ufrj.br/index.php/rl/article/view/25568.

Packer, Ian. "Krahô - Pootyt's chant". In: McCabe, Chris. Poems from the edge of extinction: an anthology of poetry in endangered languages. London: Chambers, 2019b, p.72-78

Seeger, Anthony. Por que cantam os Kisedjê. Tradução Guilherme Werlang. São Paulo: Cosac \& Naify, 2015.

Scherzer, Joel. Kuna ways of speaking. Austin: University of Texas Press, 1983. 
Scherzer, Joel. Verbal art in San Blas. Albuquerque: University of New Mexico Press, 1990.

Scherzer, Joel; Urban, Greg, (ed). Native South American Discourse. Berlin: Mouton de Gruyter, 1986.

Recebido em: 20/09/2019 Aceito em: 27/11/2019 Publicado em dezembro de 2019

Ian Packer. E-mail: ian.packer85@gmail.com ORCID:https://orcid.org/0000-0003-1663-2312 